\title{
Drip irrigation recommendations for plantain and banana grown on the semiarid southern coast of Puerto Rico, ${ }^{1,2}$
}

\author{
Ricardo Goenaga", Héber Irizarry, Bruce Coleman 5 \\ and Eulalio Ortiz
}

\begin{abstract}
Plantain and banana production in the semiarid lowlands of the southern coast of Puerto Rico has been increasing because of a greater demand for high-quality fruits, high farm-gate prices and the availability of arable land with an irrigation infrastructure. There is, however, a scarcity of information on optimum water requirements and practical irrigation recommendations for growers of these crops. Five irrigation regimes based on class $A$ pan factors, ranging from 0.25 to 1.25 were used to obtain fractions of the potential evapotranspiration and to evaluate their influence on yield and other crop traits. Results were extrapolated to make projections on productivity, gross sales, and on irrigation costs incurred in the operation of a 20-hectare farm of drip irrigated plantains or bananas. Increasing the amount of applied irrigation in a 20-hectare plantation from a pan factor of 0.75 to 1.25 increased the number of banana fruit boxes by 6,747 in the plant crop, and by 18,009 in the first banana ratoon. This irrigation increment resulted in gross sales increases of $\$ 40,482$ for the banana plant crop, and $\$ 108,054$ for the first banana ratoon, with an additional water and energy cost of only $\$ 2,388$. The net income for the plant crop and first banana ratoon irrigated according to a pan factor of 1.0 was estimated to be $\$ 51,780$ and $\$ 163,500$, respectively, in a 20 hectare banana plantation. There were no significant differences in the number of plantain fruits in irrigated plants when pan factors ranged from 0.75 to 1.25. However, irrigating plantains according to a pan factor of 1.25 significantly increased bunch yield and fruit weight. This article presents a detailed economic analysis of all the operational costs involved in the establishment and management of a banana plantation on the southern coast of Puerto Rico.
\end{abstract}

Key words: plantain, banana, drip irrigation, economic analysis, Musa spp.

'Manuscript submitted to Editorial Board 8 November 1993.

zThe authors acknowledge the excellent field assistance of Roberto Bravo and Vidal Marti during the course of this investigation.

Research Plant Physiologist, USDA, ARS, 'Tropical Agriculture Research Station, Mayagüez, Puerto Rico 00681-0070.

"Research Horticulturist, USDA, ARS, Tropical Agriculture Research Station, Mayagüez, Puerto Rico.

Agricultural Engineer, BECA, Inc., Coamo, Puerto Rico.

${ }^{6}$ Certified Public Accountant and Professor, College of Business Administration, University of Puerto Rico, Mayagüez, Puerto Rico. 


\section{RESUMEN}

Recomendaciones de riego por goteo para siembras de plátanos y guineos en la región semiárida de la costa sur de Puerto Rico

La producción de plátanos y guineos en los llanos semiáridos de la costa sur de Puerto Rico se ha ido incrementando debido a una mayor demanda por frutas de alta calidad, altos precios a nivel de la finca y a la disponibilidad de tierras mecanizables con infraestructuras para riego. Sin embargo, falta información referente a los requisitos óptimos de agua y recomendaciones de riego para estos cultivos. Se realizó un experimento para determinar los requisitos óptimos de agua y los rendimientos y costos de riego para plátano o guineo bajo riego por goteo. Los regímenes de riego se establecieron a base de evaporación medida con un evaporimetro clase A. Los resultados se extrapolaron para una siembra de 20 hectáreas. El aumentar la cantidad de riego de un factor de evaporación de 0.75 a uno de 1.25 en una siembra de 20 hectáreas resultaria en un aumento en ingreso de ventas de $\$ 40,482$ para la plantilla de guineo y de $\$ 108,054$ para el primer retoño del guineo. Los costos adicionales de agua y energia serían de solamente $\$ 2,388$. EJ mismo incremento en riego produciria 6,747 y 18,009 cajas adicionales de guineos provenientes de la plantilla y el primer retoño, respectivamente. El ingreso neto de la plantilla y el primer retoño de guineo regados de acuerdo a un factor de evaporación de 1.0 se estimó en $\$ 51,780$ y $\$ 163,500$, respectivamente, en una siembra de 20 hectáreas. No hubo diferencias significativas en el número de frutas de plátano en plantas regadas con factores de evaporación de 0.75 hasta 1.25 . Sin embargo, el riego del plátano con un factor de evaporación de $\mathbf{1 . 2 5}$ aumentó significativamente el peso de las frutas. Se presentó un estudio económico detallado de todos los costos operacionales incurridos en el establecimierito y manejo de una plantación de guineos en la costa sur de Puerto Rico.

\section{INTRODUCTION}

Plantain (Musa acuminata $\times$ Musa balbisiana, AAB) and banana (Musa acuminata AAA) are important cash crops in Puerto Rico with a combined annual farm value of $\$ 52.6$ million (Ortiz-López, 1992). Both crops are grown mainly in the mountain region where cyclical droughts reduce yields and affect fruit quality. The demand for a year-round supply of high quality fruits, the high farm prices, and the availability of arable land with an irrigation infrastructure have contributed to shifting plantain and banana production from the highlands to the fertile, but semiarid, lowlands previously used for sugar cane production. Efficient use of irrigation for plantain and banana production in this agricultural zone is imperative because of the combination of high evaporation and low rainfall.

Drip irrigation technology allows efficient use of water and can help maximize the utilization of semiarid lands for agricultural production. There is a scarcity of information regarding optimum water requirement for plantain and banana in the tropics, particularly under semiarid conditions. Both crops are known to require large quantities of well distributed water in order to attain maximum productivity and 
fruit quality as well as to ensure adequate sucker development (Abruña et al., 1980; Goenaga et al., 1993; Tai, 1977).

Other investigations (Asoegwu and Obiefuna, 1987; Hedge and Srinivas, 1990; 1989; Robinson and Alberts, 1986) have been conducted to examine the yield response of plantain and banana subjected to various irrigation regimes. However, few have reported irrigation recommendations that are readily available to growers.

Goyal and González (1988) used a modified Blaney-Criddle model to estimate the drip irrigation requirement for plantain grown in the semiarid zone of Puerto Rico. Their results indicated that a total of $149.1 \mathrm{~cm} /$ plant of drip irrigation would be required yearly for proper growth and development of plantains. However, the authors stressed the fact that their results were not substantiated by field studies.

Lahav and Kalmar (1988) conducted field studies in the northern coastal plain of Israel to study the response of drip-irrigated banana subjected to various irrigation regimes based on class A evaporation factors. Their results showed higher yields (67.9 t/ha) when plants received irrigation corresponding to a constant evaporation factor of 1.0 throughout the growing season and equivalent to 11,630 cubic meters per hectare. However, the authors did not present monthly rates of applied irrigation to demonstrate changes due to seasonal patterns.

This research was conducted to determine how marketable yield and other crop traits of plantain and banana grown in semiarid conditions under drip irrigation are influenced by five levels of irrigation based on class A pan evaporation. To provide practical irrigation recommendations to growers, we made projections on crop productivity, gross sales, and on irrigation expenses incurred in the operation of a 20 -hectare planting of drip irrigated plantain or banana.

\section{MATERIALS AND METHODS}

Field studies with plantain were conducted in 1988-89 (Goenaga et al., 1993) and with bananas during 1990-92 at the Fortuna Agricultural Research Station, latitude $18^{\circ} 2{ }^{\prime} \mathrm{N}$ and longitude $66^{\circ} 31^{\prime} \mathrm{W}$, in the semiarid agricultural zone of Puerto Rico. The soil is a Mollisol (Cumulic Haplustolls) with good drainage, a pH of 7.5, a bulk density of 1.4 $\mathrm{Mg} / \mathrm{m}^{3}, 1.7 \%$ organic carbon, and $25 \mathrm{cmol}(+) / \mathrm{kg}$ of exchangeable bases.

Corms of the horn-type Maricongo plantain cultivar or Grand Nain banana were planted in a randomized complete block design with four replications. Each replication contained five plots representing different moisture regimes. Each plantain plot was $14.6 \mathrm{~m}$ long by $1.8 \mathrm{~m}$ wide and contained two eight-plant rows. Banana plots were $21.9 \mathrm{~m}$ long by $1.8 \mathrm{~m}$ wide, and each of the two rows per plot contained 12 
plants. Plots were separated by alleys of $3.7 \mathrm{~m}$ to prevent overlapping of the irrigation treatments. The experiments were surrounded by two rows of guard plants. The population density was about 1,990 plants per hectare. Data on bunch and fruit variables were collected from 10 of the 16 plantain plants per plot, and on banana from 16 of the 24 plants per plot. Data collected for plantain are representative of the plant crop only. For banana, data were collected for the plant and first ratoon crops.

In both experiments, the equation used by Young and Pai Wu (1981) was used to calculate the amount of irrigation applied to plants. The equation assumes that the evapotranspiration of a banana or plantain mat is equal to the evaporation from a body of water with a free surface equal to the mat area as determined by a class A pan evaporimeter. In this study, the equation was modified to include a pan coefficient $(\mathrm{kp})$ value of 0.70 and a modified average crop coefficient $\left(\mathrm{k}_{\mathrm{c}}\right)$ of 0.88 (Doorembos and Pruitt, 1977) to obtain a theoretical value of potential evapotranspiration. Class A pan factors (proportion of pan evaporation), which ranged from 0.25 for treatment 1 to 1.25 for treatment 5 in 0.25 increments, were used to obtain fractions of the potential evapotranspiration. A pan factor of 1.0 means that the water applied to the plants of that treatment replaced that lost through evapotranspiration and hence was considered the theoretical optimum.

The plants were subjected to the five moisture regimes two and a half months after planting. The amount of water applied varied weekly depending on class A pan evaporation and rainfall. The previous week's evaporation and rainfall data were used to determine the irrigation needs for the following week. Irrigation was supplied three times the following week on alternate days, and no irrigation was provided when the total rainfall exceeded $19 \mathrm{~mm}$ per week.

In both experiments, submain lines were equipped with volumetric metering valves to monitor the water provided to each treatment. Lateral lines branched out from the submains along the inner side of each of the two rows of plants and about $46 \mathrm{~cm}$ apart from the pseudostem base. Two in-line $8 \mathrm{~L} / \mathrm{h}$ emitters were spaced $21 \mathrm{~cm}$ from the pseudostems, and two feeder lines with $4 \mathrm{~L} / \mathrm{h}$ emitters provided a uniform supply of water around each plantain plant. In the banana experiment, laterals were equipped with built-in $4 \mathrm{~L} / \mathrm{h}$ emitters spaced $61 \mathrm{~cm}$ apart along the line and feeder lines were not used.

At planting, each plantain and banana plant received $11 \mathrm{~g}$ of granular $\mathrm{P}$ provided as triple superphosphate. Plantain plants were fertigated weekly at the rate of 8.6 and $14.4 \mathrm{~kg} / \mathrm{ha}$ of $\mathrm{N}$ and $\mathrm{K}$, respectively, with urea and potassium nitrate serving as sources of these 
nutrients. Banana plants were fertigated weekly at rates of $10.2 \mathrm{~kg} / \mathrm{ha}$ of $\mathrm{N}$ and $28.5 \mathrm{~kg} / \mathrm{ha}$ of $\mathrm{K}$ from potassium nitrate. Banana weekly fertigations also included 0.26 and $0.08 \mathrm{~kg} / \mathrm{ha}$ of $\mathrm{Zn}$ and Fe supplied in their EDTA chelate forms and $0.29 \mathrm{~kg} / \mathrm{ha}$ of $\mathrm{Mn}$ supplied as DTPA chelate. When irrigation was not necessary because of rainfall, weekly fertigation was postponed and rates were doubled the following week. Recommended cultural practices (Agricultural Experiment Station, 1986) were followed regarding bunch and sucker management and pesticide and herbicide applications. Plantain bunches were harvested when the fruits reached the mature green stage, and banana when the fruits were three-fourths full, about 120 days after flowering. Collected data were subjected to an analysis of variance using the ANOVA procedure of the SAS program package (1987). All references to differences among means were considered to be significant at the 0.05 probability level or lower.

Rainfall and evaporation data collected from 1988 to 1992 were used to calculate the amount of applied irrigation during the field plantings. However, final drip irrigation recommendations for these crops were calculated by also including historical weather data collected at the research station from 1982 to 1987, and assuming that both crops had been grown at the test site during an 11-year period (i.e., 1982 to 1992 ; Table 1).

Projections on energy costs (Table 4) for the irrigation of a 20 -hectare farm were based on the following assumptions: 1) Farm is divided into four 5-ha sections, each of which receives irrigation separately; 2) Use of a 40 brake horsepower motor pump with an efficiency of $75 \% ; 3$ ) A total dynamic head of $61 \mathrm{~m}$ discharges $1,977.7 \mathrm{~L} / \mathrm{min}$ of water to each 5-ha section; 4) Pumping time to each 5-ha section on a given day is 1.7, 2.3 , and 2.8 hours for pan factors of $0.75,1.0$, and 1.25 , respectively; 5 ) Under the 711 agricultural tariff provided by the Electric Energy Authority, the cost per kilowatt hour is 0.054 cents; therefore, the total kilowatt hour consumption per year was estimated at $31,619.99$, $42,160.08$, and $52,699.98$ for pan factors $0.75,1.0$, and 1.25 , respectively; 6) Energy costs also include fuel adjustment and minimum charge costs of 0.033 cents and $\$ 120.00$, respectively. The cost of well water (Table 4) is based on a charge by the Department of Natural Resources of $\$ 25.00$ per 3,785,000 liters of water.

Table 5 provides a detailed economic analysis of all the operational costs and net income generated in the establishment and management of one hectare of bananas. The data were obtained from growers, federal and state government agencies, private financial institutions, and distributors of agricultural products. Projections of operational costs 
TABLE: 1.-Average and standard deviation for monthly evaporation and rainfall registered at the Fortuna Agricultural Station from 1982 to 1992.

\begin{tabular}{lccc}
\hline Month & $\begin{array}{c}\text { Class A } \\
\text { evaporation } \\
(\mathrm{mm})\end{array}$ & $\begin{array}{c}\text { Rainfall } \\
(\mathrm{mm})\end{array}$ & $\begin{array}{c}\text { Evaporation-rainfall } \\
\text { difference } \\
(\mathrm{mm})\end{array}$ \\
\hline January & $150.9 \pm 15.9$ & $38.2 \pm 65.1$ & 1.12 .7 \\
February & $154.5 \pm 9.3$ & $24.0 \pm 15.1$ & 130.5 \\
March & $192.5 \pm 14.2$ & $45.4 \pm 51.6$ & 147.1 \\
April & $193.5 \pm 13.5$ & $58.4 \pm 51.4$ & 135.1 \\
May & $179.9 \pm 33.4$ & $144.3 \pm 151.2$ & 35.6 \\
June & $195.7 \pm 15.6$ & $49.8 \pm 56.4$ & 14.9 \\
July & $207.9 \pm 22.9$ & $56.7 \pm 37.4$ & 151.2 \\
August & $209.7 \pm 11.5$ & $89.3 \pm 83.1$ & 120.4 \\
September & $175.1 \pm 18.9$ & $109.5 \pm 73.9$ & 65.6 \\
October & $155.0 \pm 23.2$ & $192.8 \pm 220.0$ & -37.8 \\
November & $134.1 \pm 14.1$ & $148.6 \pm 108.0$ & -14.5 \\
December & $137.6 \pm 14.0$ & $16.7 \pm 15.5$ & 120.9 \\
Total & 2086.4 & 973.7 & \\
Average & $173.9 \pm 31.1$ & $81.1 \pm 106.2$ & \\
\hline
\end{tabular}

included the following assumptions: 1) salaries of $\$ 3.50 /$ hour; 2 ) a plant population density of 1,990 plants/ha; 3) grower participation of the Puerto Rico Department of Agriculture's incentive program for the application of nematicide. Because of the seasonal and often large market-price fluctuations for plantains, a similar economic analysis for this crop was not made. However, if the operational costs involved in the establishment and management of a plantain farm are known, the gross sales reported in this manuscript for drip-irrigated plantains may be helpful to estimate the net income at prevailing market conditions.

\section{RESULTS AND DISCUSSION}

Field studies

For the 11 years of weather data used in this study, total class A pan evaporation at the Fortuna Agricultural Station was two times greater than the amount of total rainfall (Table 1). This ratio is similar to that obtained using the available historical data collected for more than 20 years at the same location, which show annual evaporation and rainfall values of 2,149 and $917 \mathrm{~mm}$, respectively (Goyal and González, 1989). This finding indicates that the study period was representative of the normal climate conditions that prevail in this agricultural zone. 


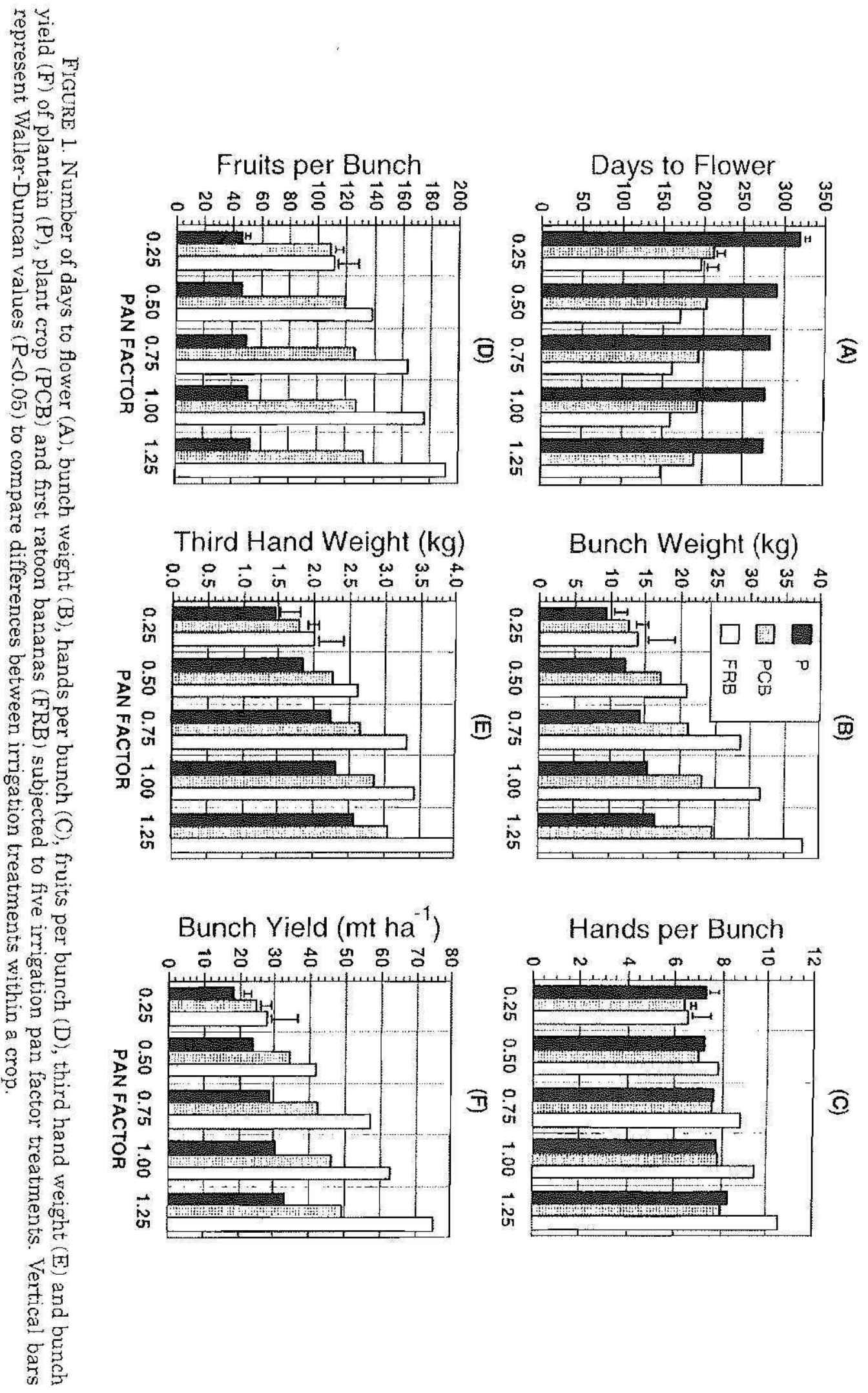

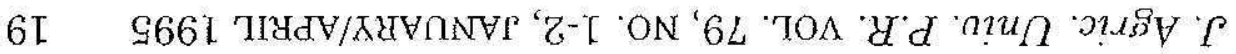


Increases in pan factor treatments caused a significant reduction in the number of days required to flower (bunch shooting), and consequently the planting to harvest cycle was shortened in both plantain and banana (Figure IA). Plantain, plant crop banana (PCB) and first ratoon banana (FRB) replenished with 100\% of the water lost through evapotranspiration (pan factor 1.0) flowered at about 277, 193 and 352 days after planting, respectively. As compared to plants replenished with a pan factor of 0.25 , plantains, $\mathrm{PCB}$ and FRB replenished with a pan factor of 1.0 flowered 43,17 and 36 days earlier, respectively. Days to flowering in PCB ranged by only 22 days in plants subjected to treatment extremes (i.e., pan factors 0.25 and 1.25). This response contrasted with that observed for plantain and FRB and was probably the result of abnormally high rainfall (totalling $711 \mathrm{~mm}$ during the last four months of 1990), which probably allowed drought-stressed plants from the low pan factor treatments to develop faster.

Maximum plantain and PCB bunch weights (16.5 and $24.5 \mathrm{~kg}$, respectively) were obtained with the use of pan factor 1.25. Although statistical differences in plantain and PCB bunch weights were not observed between pan factors 1.25 and 1.0 , significant differences existed between pan factors 1.25 and 0.75 (Figure 1B). The greatest response to irrigation treatments was obtained for FRB plants, which produced maximum bunch weights of $37.6 \mathrm{~kg}$, using a pan factor of 1.25 (Figure 1B). This response represented an increase of $172,80,24$, and $19 \%$ as compared to FRB plants that received pan factor treatments of 0.25 , $0.50,0.75$, and 1.0 , respectively.

The total number of hands per bunch ranged from 7.2 to 8.3 in plantains subjected to the five irrigation regimes (Figure 1C). The number of hands per bunch in plantain plants irrigated with a pan factor of 1.25 was significantly greater than those produced in the remaining irrigation treatments (Figure 1C). The number of hands per bunch in PCB and FRB plants significantly increased with increases in pan factor treatments. This response was more evident in FRB plants which produced four more hands per bunch with a pan factor of 1.25 than with 0.25 (Figure 1C).

As a consequence of the increase in the number of hands per bunch with increments in pan factor treatments, the number of fruits per bunch increased from 111 to 190 fruits in FRB plants receiving pan factor treatments of 0.25 and 1.25 , respectively (Figure 1D). The average number of fruits per bunch in PCB plants subjected to the higher three pan factor treatments was 128 , whereas it was 155 in FRB plants. In plantain, the number of fruits per bunch significantly increased from 45 to 52 in plants irrigated with pan factors of 0.25 and 1.25 , respec- 
tively (Figure 1D). There were no significant differences in the number of fruits per bunch in irrigated plantain plants when pan factors ranged from 0.75 to 1.25 .

The first three upper hands of plantain bunches contain about $50 \%$ of the total fruits and about $40-45 \%$ in banana bunches. Therefore, the weight of the third upper hand is often used to represent an average weight of all the hands in a bunch. Pan factor treatments significantly affected the weight of the bunch's third upper hand in plantain, PCB, and FRB plants (Figure 1E). In plantain, however, there were no significant differences in the weight of the bunch's third upper hand from plants irrigated with pan factors of 0.75 and 1.0 , but the differences between 0.75 and 1.25 were significant. This response greatly contrasted with that observed in PCB and FRB plants, in which practically each pan factor increment resulted in a significant increase in the weight of the third upper hand (Figure 1E).

The highest yields for plantain, PCB and FRB plants were 33,49 , and $75 \mathrm{t} / \mathrm{ha}$, respectively, and were obtained with the application of a pan factor treatment of 1.25 (Figure 1F). Although statistical differences in plantain and PCB yields were not observed between pan factors 1.25 and 1.0 , both crops showed that yields obtained with a pan factor of 1.25 were significantly greater than those obtained with a pan factor of 0.75 (Figure $1 F$ ). Yields of FRB plants irrigated with a pan factor of 1.25 were significantly greater than those obtained in the remaining pan factors.

Irrigation Recommendations

The results presented in this study demonstrate the importance of irrigation to obtain adequate yields in plantain and banana grown in the semiarid zone of Puerto Rico.

On the basis of our field studies and historical weather data, Table 2 presents the monthly amounts of irrigation that would be applied to plantain and banana subjected to five irrigation regimes in the semiarid zone of Puerto Rico.

Less irrigation was required during the months of September through November whereas March, April, July and August demanded higher quantities of irrigation (Table 2). October and November were the only months in which rainfall exceeded Class A pan evaporation. In most of the remaining months of the year, pan evaporation exceeded rainfall by over $100 \mathrm{~mm}$ (Table 1 ).

Based on plantain and banana irrigation requirements (Table 2), and the yield and fruit quality data obtained from our field studies (Figures 1B-F), we estimated the yearly gross sales and irrigation costs 
TABLE 2,-Monthly amount of water applied to plantains or bananas subjected to five. irrigation treatments on the semiarid southern coast of Puerto Rico.

\begin{tabular}{|c|c|c|c|c|c|}
\hline \multirow[b]{3}{*}{ Month } & \multicolumn{5}{|c|}{ Supplied irrigation (L per plant) } \\
\hline & \multicolumn{5}{|c|}{ Pan factor treatment } \\
\hline & 0.25 & 0.50 & 0.75 & 1.0 & 1.25 \\
\hline January & 97 & 194 & 291 & 388 & 485 \\
\hline February & 98 & 195 & 293 & 391 & 489 \\
\hline March & 120 & 240 & 361 & 481 & 601 \\
\hline April & 103 & 206 & 309 & 412 & 515 \\
\hline May & 75 & 150 & 225 & 300 & 375 \\
\hline June & 99 & 199 & 298 & 397 & 497 \\
\hline July & 118 & 236 & 354 & 473 & 591 \\
\hline August & 109 & 218 & 328 & 437 & 546 \\
\hline Septembex & 65 & 131 & 197 & 263 & 328 \\
\hline October & 59 & 118 & 178 & 237 & 296 \\
\hline November & 39 & 77 & 116 & 154 & 193 \\
\hline December & 88 & 175 & 263 & 351 & 439 \\
\hline Total & 1,070 & 2,139 & 3,213 & 4,284 & 5,355 \\
\hline Average & 89 & 178 & 268 & 357 & 446 \\
\hline
\end{tabular}

incurred by a grower operating a 20-hectare planting irrigated with pan factors of $1.25,1.0,0.75$. Irrigation with lower pan factors was detrimental to yield and fruit quality and therefore was not considered in our analyses.

Increasing the amount of applied irrigation from pan factor 0.75 to 1.25 resulted in gross sales increases of $\$ 40,482$ for $\mathrm{PCB}$ and $\$ 108,054$ for FRB (Table 3). However, the increase in the amount of supplied irrigation resulted in an additional energy and water cost of only $\$ 2,388.52$ (Table 4). It is noteworthy that increasing the pan factor from 0.75 to 1.25 increased the number of fruit boxes by 6,747 in PCB. However, the same irrigation increment in FRB resulted in 18,009 additional boxes (Table 3 ).

There were no significant differences in the number of plantain fruits from plants irrigated with pan factors ranging from 0.75 to 1.25 (Figure 1; Table 3). Nevertheless, variables such as bunch weight, weight of the third upper hand, number of hands, and total yield were significantly greater in plants irrigated with a pan factor of 1.25 than in those irrigated with a pan factor of 0.75 (Figure 1). Moreover, the average plantain fruit weight from plants irrigated with a pan factor of 0.75 and 1.25 was 290 and $316 \mathrm{~g}$, respectively (data not shown). This finding indicates that plantain irrigation with a pan factor of 1.25 re- 
TABLE 3.-Estimated yield and gross sales of plantain or banana supplied with three levels of irrigation based on class A pan evaporation factors in a 20-hectare planting on the southern coast of Puerto Rico.

\begin{tabular}{|c|c|c|c|c|c|c|c|c|}
\hline \multirow[b]{2}{*}{ Pan Factor } & \multicolumn{2}{|c|}{ Plantain } & \multicolumn{3}{|c|}{ Plant Crop Banana } & \multicolumn{3}{|c|}{ First Ratoon Banana } \\
\hline & $\begin{array}{c}\text { Fruits' } \\
\text { (no//20 ha) }\end{array}$ & $\begin{array}{c}\text { Gross sales } \\
\text { (U.S. } \$)\end{array}$ & $\begin{array}{c}\text { Bunch Yield }{ }^{1} \\
(\mathrm{~kg})\end{array}$ & $\begin{array}{c}\text { No. of Boxes } \\
\text { of fruits }\end{array}$ & $\begin{array}{l}\text { Gross sales }{ }^{2} \\
\text { (U.S. \$) }\end{array}$ & $\begin{array}{l}\text { Bunch Yield } \\
\text { (kg) }\end{array}$ & $\begin{array}{l}\text { No. of Boxes } \\
\text { of fruits }\end{array}$ & $\begin{array}{c}\text { Gross sales } \\
\text { (U.S. \$) }\end{array}$ \\
\hline 0.75 & $1,657,458$ & 198,895 & 757,800 & 41,775 & 250,650 & $1,022,400$ & 56,362 & 338,172 \\
\hline 1.00 & $1,712,673$ & 205,521 & 828,000 & 45,645 & 273,870 & $1,129,950$ & 62,290 & 373,740 \\
\hline 1.25 & $1,771,953$ & 212,634 & 880,200 & 48,522 & 291,132 & $1,349,100$ & 74,371 & 446,226 \\
\hline Waller $(0.05)$ & 115,097 & $\ldots$ & 60,010 & 3,308 & - & 245,524 & 8,022 & - \\
\hline
\end{tabular}

Values reflect a $15 \%$ and $10 \%$ yield reduction for plantain and bananas, respectively, due to losses caused by wind damage, non-productive plants, and other factors that may reduce production in a commercial plantation. The mean number of fruits per plantain bunch for the three pan factors was 50.6 with an average of $304 \mathrm{~g}$ per fruit. For PCB and FRB, the average number of hands per bunch was 7.8 and 9.6 , respectively, with an average hand weight of $2.9 \mathrm{~kg}$ for $\mathrm{PCB}$ and 3.4 for $\mathrm{FRB}$.

"Sales based on $\$ 120.00$ per 1,000 marketable plantain fruits and $\$ 6.00$ per banana box weighing $18.14 \mathrm{~kg}$. 
TABLE 4.--Yearly irrigation (liters/20 ha), energy and water costs (U.S. \$) required for plantain or banana production under three irrigation regimes in a 20-hectare planting on the semiarid southern const of Puerto Rico.

\begin{tabular}{lcccc}
\hline Pan Factor & $\begin{array}{c}\text { Yearly supplied } \\
\text { irrigation' }\end{array}$ & $\begin{array}{c}\text { Yearly energy } \\
\text { cost }\end{array}$ & $\begin{array}{c}\text { Yearly water } \\
\text { cost }\end{array}$ & $\begin{array}{c}\text { Total energy } \\
\text { and water costs }\end{array}$ \\
\hline 0.75 & $125,788,950$ & $2,871.96$ & 830.84 & $3,702.80$ \\
1.00 & $167,718,096$ & $3,789,28$ & $1,107.78$ & $4,897.06$ \\
1.25 & $209,648,250$ & $4,706.59$ & $1,384.73$ & $6,091.32$ \\
\hline
\end{tabular}

Irrigation recommendations were based on the following assumptions: a plant population of about 39,840 plants/20 ha planted at a distance of $1.8 \times 1.8 \times 3.7 \mathrm{~m} ; 156 \mathrm{irri}$ gation applications per year, which is equivalent to three applications per week. Each plant was provided with drip lines equipped with $4 \mathrm{~L} / \mathrm{hr}$ emitters spaced $61 \mathrm{~cm}$ apart.

sults in an improvement in fruit quality and probably greater gross sales since plantains are marketed by fruit units which must weigh 270 $\mathrm{g}$ or more to be considered marketable.

On the basis of the economic analysis provided in Table 5 and the yield data for banana contained in Table 3 , we estimated the net income to be $\$ 51,780$ in the plant crop and $\$ 163,500$ in the ratoon crop when 20 hectares are irrigated with a pan factor of 1.0. The increase in the net income for the ratoon crop was the combined result of a $36 \%$ yield increase (Table 3 ) and lower operational costs associated with less use of labor and operation of machinery (Table 5).

TABLE 5.-Approximate costs and income per hectare for the production of a plant crop and first ratoon bananas grown under drip irrigation in the semiarid region of Puerto Rico using a plant population density of about 1,990 plants.

\begin{tabular}{|c|c|c|c|}
\hline Item & Unit & Quantity & $\operatorname{Cost}(\$)$ \\
\hline \multicolumn{4}{|l|}{ Labor } \\
\hline 1. Land preparation ${ }^{1}$ & man/days & 3.7 & 104.00 \\
\hline 2. Digging, cleaning and planting of suckers & " & 17.3 & 484.00 \\
\hline 3. Post planting cultivation (twice) & $"$ & 2.5 & 70.00 \\
\hline 4. Herbicide application ( 3 applications) & $"$ & 3.7 & 104.00 \\
\hline 5. Fertilization through drip system & $"$ & 4.9 & 137.00 \\
\hline 6. Desuckering and removal of dead leaves & $"$ & 22.2 & 622.00 \\
\hline 7. Supporting plants with twine & " & 17.8 & 498.00 \\
\hline 8. Bunch bagging & " & 8.8 & 246.00 \\
\hline 9. Spraying against Sigatoka (2 applications) & $"$ & 1.2 & 34.00 \\
\hline 1.0. Miscellaneous chores & $"$ & 5.0 & 140.00 \\
\hline 11. Harvest, transportation and packing & $"$ & 76.2 & $2,134.00$ \\
\hline Total Labor Plant crop & $"$ & 163.3 & $4,573.00$ \\
\hline Total Labor xatoon crop & $"$ & 142.3 & $3,985.00$ \\
\hline
\end{tabular}

Not considered for ratoon crop. 
TABLE 5.-Approximote costs and income per hectare for the production of a plant crop and first ratoon banutas grown under drip irrigation in the semiarid region of Puerto Rico using a plant population density of about 1,990 plants. (Cont.)

\begin{tabular}{|c|c|c|c|}
\hline Item & Unit & Quantity & Cost (\$) \\
\hline \multicolumn{4}{|l|}{ Supplies and materials } \\
\hline \multicolumn{4}{|l|}{ 1. Fertilizer } \\
\hline - Urea & $\mathrm{kg}$ & 659 & 266.00 \\
\hline - Potassium Sulfate & $\mathrm{kg}$ & 1795 & 756.00 \\
\hline - Phosphoric acid (6 applications) & liters & 147 & 310.00 \\
\hline 2. Nematicide & $\mathrm{kg}$ & 113 & 560.00 \\
\hline 3. Herbicide & liters & 14 & 208.00 \\
\hline 4. Fungicide (2 applications of 'Tilt)" & liters & 1.0 & 66.00 \\
\hline 5. Polyethylene bunch bags & bags & 1990 & 338.00 \\
\hline 6. String & spools & 6.7 & 80.00 \\
\hline 7. Miscellaneous supplies & - & - & 124.00 \\
\hline Total Supplies and Materials & & & $2,708,00$ \\
\hline \multicolumn{4}{|l|}{ Other Costs } \\
\hline 1. Electricity & ha & 1 & 186.00 \\
\hline 2. Irrigation water (pan factor 1.0 ) & ha & 1 & 55.00 \\
\hline 3. Use of land and irrigation equipment & ha & 1 & 618.00 \\
\hline $\begin{array}{l}\text { 4. Use of equipment (tractor, cultivator, sprayer, } \\
\text { drip system; includes repair maintenance and } \\
\text { depreciation) }\end{array}$ & ha & 1 & 370.00 \\
\hline $\begin{array}{l}\text { 5. Payroll taxes (Social Security, state, } \\
\text { unemployment, christmas bonus, vacations)" }\end{array}$ & ha & 1 & $1,120.00$ \\
\hline 6. Financing interests through assignment: & ha & 1 & 529.00 \\
\hline 7. Crop Insurance; & ha & 1 & 332.00 \\
\hline 8. Supervision (other than owner) & ha & 1 & 495.00 \\
\hline 9. Fuel and oil & ha & 1 & 55.00 \\
\hline 10. Financing interests on equipment $(9.75 \%)$ & hat & 1 & 62.00 \\
\hline Total other costs & ha & 1 & $3,822,00$ \\
\hline
\end{tabular}

"Trade names in this publication are used only to provide specific information. Mention of a trade name does not constitute a warranty of equipment or materials by the Agricultural Experiment Station of the University of Puerto Rico, nor is this mention a statement of preference over other equipment or materials.

${ }^{3} \mathrm{About} 24.5 \%$ of labor costs.

${ }^{4} \mathrm{Crop}$ average costs at $10 \%$ interest.

Insurance covers $75 \%$ of the plantation (1,493 plants) at a cost of $\$ 4.77$ for each $\$ 100.00$ insured. 
TABLE 5.-Approximate costs and income per hectare for the production of a plant crop and first ratoon bananas grown under drip irrigation in the semiarid region of Puerto Rico using a plant population density of about 1,990 plants. (Cont.)

\begin{tabular}{lcrc}
\hline \multicolumn{1}{c}{ Item } & Unit & Quantity & Cost (\$) \\
\hline Income & & & \\
1. Sale of high grade fruit:s: & & & \\
- Plant crop & boxes/ha & 2,282 & $13,692.00$ \\
- Ratoon crop & boxes/ha & 3,115 & $18,690.00$ \\
2. Net income & ha & 1 & $2,589.00$ \\
- Plant crop & ha & 1 & $8,175.00$ \\
- Ratoon crop & & & \\
\hline
\end{tabular}

The net income may increase by about $\$ 1,166.00$ in the plant crop and by $\$ 1,022.00$ in the ratoon crop if reimbursements for supplementary salaries at the rate of $\$ 7.00$ for each man-day is considered. Also it is assumed that the buyer supplies the packing boxes. For income taxes, only $10 \%$ of the annual net income will be taxed at rates not exceeding $36 \%$.

$\$ 6.00 / \mathrm{box}$ of $18.14 \mathrm{~kg}$.

These results provide evidence on the importance of proper irrigation management for plantain and banana production on the southern coast of Puerto Rico and show that the additional costs brought about by the increments in irrigation are compensated by improved fruit quality and higher yields. We therefore recommend irrigation according to a pan factor of at least 0.75 for plantains and 1.0 for bananas to attain optimum growth and yields.

\section{LITERATURE CITED}

1. Abruña, F., J. Vicente-Chandler and S. Silva, 1980. Evapotranspiration with plantains and the effect of frequency of irrigation on yields. J. Agric. Univ. P.R. 64(2):204-210.

2. Agricultural Experiment Station, 1986. Technological package for the production of plantains and bananas. Publication 97. Agricultural Experiment Station, College of Agricultural Sciences, Mayaguez, Puerto Rico (In Spanish).

3. Asoegwu, S. N. and J. C. Obiefuna, 1987. Effect of irrigation on late season plantains. Tropical Agriculture 64(2):139-143.

4. Doorenbos, J. and W. O. Pruitt, 1977. Guidelines for predicting crop water requirements, Irrigation and Drainage paper 24, FAO, United Nations, Rome, litaly.

5. Goenaga, R., H. Irizarry and E. González, 1993. Water requirement of plantains (Musa acuminata $\times$ Musa balbisiana $\mathrm{AAB}$ ) grown under semiarid conditions. Tropical Agriculture 70(1):3-7.

6. Goyal, M. R. and E. A. González, 1989. Climatological data collected in the agricultural experiment stations of Puerto Rico. Publication 88-70. Agricultural Experiment Station, College of Agricultural Sciences, Mayaguez, Puerto Rico (In Spanish). 
7. Goyal, M. R. and E. A. González, 1988. Irrigation requirements for plantain in seven ecological zones of Puerto Rico. J. Agric. Uniu. P.R. 72(4):599-608 (In Spanish).

8. Hedge, D. M. and K. Srinivas, 1990. Growth, productivity and water use of banana under drip and basin irrigation in relation to evaporation replenishment. Indian of. Agron. 35(1-2):106-112.

9. Hedge, D. M. and K. Srinivas, 1989. Irrigation and nitrogen fertility influences on plant water relation, biomass, and nutrient accumulation and distribution in banana cu. Robusta d. Hort. Sci. 64(1):91-98.

10. Lahav, E. and D. Kalmar, 1988. Response of banana to drip irrigation, water amounts and fertilization regimes. Commun. Soil Sci. Plant Anal. 19(1):25-46.

11. Ortiz-López, J., 1992. Plantain and Banana. p.123-138. In: C. I. Alamo (ed.) Situation and Perspectives of Agricultural Enterprises in Puerto Rico during 1990-1991. Agricultural Experiment Station, College of Agricultural Sciences, Mayaguez, Ptzerto Rico (In Spanish).

12. Robinson, J. C. and A. J. Alberts, 1986. Growth and yield responses of banana (cultivar 'Williams') to drip irrigation under drought and normal rainfall conditions in the subtropics. Scientia Horticulturae 30:187-202.

13. SAS Institute, Inc, 1987. SAS/STAT Guide for Personal Computers, Raleigh, North Carolina.

14. Tai, E. A. 1977, Banana. p. 441-460. In: Alvim, P. de T. and Kozlowski, T. T. (eds.) Ecophysiology of Tropical Crops. Academic Press, New York, N.Y.

15. Young, S. and I-Pai Wu, 1981. Proceedings of XIII Annual Meeting, p. 51-69. Conference Research Extension Series 021, College of Tropical Agriculture and Human Resources, Univ. Hawaii. 